\title{
HEALTH AND HOSPITAL DEVELOPMENT IN NEPAL: PAST AND PRESENT
}

\author{
Marasini B R
}

\section{INTRODUCTION}

Health and hospitals are very important components of every nation. All nations have their own history of health and hospital development. It is very difficult to identify the exact date of hospital development in Nepal as many areas of the Nepalese history are missing. Nepal has its' own system of indigenous system of medicine which remained mainstream health system till initial part of modern Nepal. Lack of research, inability to adopt scientific developments in diagnosis and treatment and unavailability of formal education system made it less efficient system that couldn't solve the major health problems. This led to search of more efficient health system and paved the road for western medicine or allopathic system of medicine.

Health and religion were interrelated in ancient days. All major religions had important role to develop and promote education and medicine. In earlier days the Christian Mission offices established in many countries had multiple roles and one of them was health and medicine. Medical doctors sent through the Christian Missions, introduced modern medicine hospitals in many parts of the world. In Nepal also the modern or allopathic medicine was introduced by Christian Missionaries in sixteenth century, which could not continue for long time because of religious, and to some extent political factors.

\section{HISTORICAL ERAS OF HEALTH AND HOSPITAL DEVELOPMENT}

Historians have divided Nepalese history into ancient (first century to $879 \mathrm{AD}$ ), medieval ( $879 \mathrm{AD}$ to till control of the Kathmandu by King Prithvi Narayan Shah-1768 AD) and modern Nepal from 1769 AD onwards. The health development history also can be divided in the same way but the modern era for health should rather be considered from $1889 \mathrm{AD}$ as a landmark of establishing the hospitals by the Nepal government to provide health services to common people as a state initiative.

\section{HEALTH AND HOSPITAL DEVELOPMENT DURING ANCIENT ERA}

The history of health and hospital development dates back to the ancient Nepal or Lichchhavi period. In the reign of the Amshu Verma (605-620 AD) one of the historical document found in $604 \mathrm{AD}$ has mentioned about the Aarogyashala or hospital (probably Ayurvedic), but no elaborate explanations has been found. ${ }^{1}$ Descriptions of Aarogyashala can be found in the reign of the Lichchhavi Kings Narendra Dev (643-679 AD) and Man Dev (464-505 AD) too. Lichchhavi Kings also issued rules and directives to be followed by the general population on the safe motherhood practices. These directives were - separation of mother and baby before last rites are performed in case of death of the pregnant women with baby in utero, and identifying husband responsible for care of the pregnant and post natal wife and warning punishment in case of negligent behavior or death (Narendra Dev). Lastly, cutting umbilical cord immediately after the baby is born and not to wait till the placenta is expelled (Amshu Verma). ${ }^{2}$

\section{HEALTH AND HOSPITAL DEVELOPMENT DURING MEDIEVAL ERA}

In the medieval era no continuity of Aarogyashalas or hospitals established during the Lichchhavi period can be found. It can be presumed that the medicine became a family business rather than a state business after the Lichchhavi period. In the Malla period the King of the Kantipur, Pratap Malla (1641-1674 AD) established a traditional medicine (Ayurvedic) dispensary for common people at Royal Palace complex in Hanumandhoka, Kathmandu. King Pratap Malla and Malla Kings of Bhaktapur and Patan encouraged Ayurvedic system of medicine by asking to prepare books in Ayurveda and creating opportunities for professional training. It is widely believed that the current Singh Darbar Baidyakhana or Traditional Medicine Manufacturing Plant is the continuity of the dispensary established earlier by the King Pratap Malla.

Address for correspondence : $\quad$ Dr. Babu Ram Marasini 
Before being shifted to the current place it was shifted in the Thapathali Darbar complex, residential palace of the then Prime Minister Jung Bahadur Rana. ${ }^{3}$

\section{INTRODUCTION OF ALLOPATHIC MEDICINE BY CHRISTIAN MISSIONARIES IN MALLA PERIOD}

The first introduction of the modern medicine or allopathic system of medicine in Nepal was done by the Christian Missionaries working in Peking, China and Lhasa, Tibet. In those days one of the Trans-Himalayan trade route was via Kathmandu and the Christian Missionaries have used the road and have felt health needs of the then Nepal. In 1624 AD Father D'Andrada went Tibet via the Himalayan route and it is not clear whether he went through the Kathmandu or used other route but has mentioned meeting the Nepalese and familiarity of Nepali people with Christian religion. He has not mentioned about the medical service. In 1661 AD Jesuit Father Grueber and Dorville and associates entered Nepal via Lhasa from Christian Mission office in Peking. At that time Pratap Malla was the King in Kantipur, Siddinarsingh Malla in Patan and Jagajyoti Malla in Bhaktapur and it has been mentioned in the history that Father Grueber and his associates met the King Pratap Malla initially and presented one binocular and other mathematical instruments. With this Pratap Malla became very happy and he allowed missionaries to work in the Kantipur. Other cause of permission could be periodical epidemic of plague and cholera in Kathmandu, which were serious health problems, and the king might have heard about the prevention and treatment from the missionaries. After receiving permission from the king missionary team started health service, school education and Christian religious activities such as education and preaching. They received good appreciation from people of Kathmandu valley on preventing plague especially in children. But King Siddi Narsingh Malla (1621-1661) of Patan was unhappy with the act of the Jesuit Father Dorville and his associates as they begun to distribute the food to people and involved them in preaching. All of them were expelled from the country. $4,5,6$

The missionary Fathers used Kathmandu as the temporary station for to and fro travel to China or Tibet office. Father Tavernier replaced the Jesuit father Grueber, and probably he went to Lhasa via Kathmandu. Jesuit Father Desideri entered Nepal from Lhasa at the time of King Bhupatindra Malla of Bhaktapur (1696-1722). Father Grueber and his associates were placed again in Tibet and there was some conflict between the Jesuit mission and the regular missionaries in Lhasa office and the then pope of the Vatican replaced the Jesuit mission with the capuchin monks. Capuchin monks established a small mission office in Kathmandu in 1715 AD but the hostility shown by the Brahmins of the Kathmandu drove them to take shelter in Bhaktapur. After this incident Capuchin Father Horrace della Penna went back to Rome, from Kathmandu opposing the expulsion, and returned Bhaktapur in 1741 AD. Another group headed by Father De Recanti continued to work in Bhaktapur and it is widely believed that he also established a missionary office in Bettiah too, a small state in Indo-Nepal border. He initially entered in Bhaktapur at the time of the King Ranjit Malla (1722-1769 AD). Later in 1745 AD the capuchin monks working in Lhasa office were driven out by the administration of Tibet and all of them gathered in Kathmandu valley. It has been mentioned in the history that in 1750s all three kingdoms of Kathmandu had Christian mission offices and medical clinics. ${ }^{6}$

Movement of unification of small kingdoms under a greater Nepal was started by the King of Gorkha, Prithvi Narayan Shah (1733-1772 AD) and several kingdoms west of Kathmandu valley then unified with the Gorkha kingdom. Unification campaign started within the Kathmandu valley too and as the Kantipur kingdom was very powerful out of the three kingdoms of valley, the war broke out with the Kantipur. Second war broke in 1763 AD between the Kantipur and Gorkha at Kirtipur and Prince Soor Pratap Shah of Gorkha got injury in eye. The capuchin monk Michael Angelo was called and he treated the wounded prince. ${ }^{7}$

\section{DISCONTINUITY OF MODERN MEDICAL SERVICES}

In $1768 \mathrm{AD}$ unification of the kingdom of the Kantipur and Patan completed. The last kingdom remaining in the valley was Bhaktapur and it was unified in 1769 AD. After the control over the valley the new administration reviewed role of Christian Mission offices and adopted policy of "with the bible bayonet comes and with the missionary musket comes'. The new administration in Kathmandu considered them as representatives of overall European policy rather then the Christian religion. The Gorkhalis were also suspicious with monk's role in dispatching the army by the East India Company to help the last King of Kantipur, Jaya Prakash Malla. With all these issues the then administration decided to close mission offices including medical clinics and expelled all the capuchin monks and their Nepali followers from Nepal and they left for the mission office in Bettiah. 6,7

The expulsion of the capuchin monks from the Kathmandu valley represents the closure of the initial part of the history of modern medicine in Nepal. Though the capuchin monks expelled from the country, but it has been mentioned in the history that they came to Kathmandu on request to treat King Singh Pratap Shah, who was suffering from smallpox, but 
despite treatment he died in $1777 \mathrm{AD} .{ }^{7}$ There is no mention of the use of modern medicine or establishment of hospitals till another 120 years. Ayurvedic medicine continued to be the main health system of the country.

\section{HEALTH AND HOSPITAL DEVELOPMENT IN MODERN ERA}

The modern era also can be divided into three phases - first phase medical service from British resident doctors, second phase the Rana period and the third phase the post democracy period. Reintroduction of modern medicine and expansion of medical services and institutionalization of Ayurvedic system of medicine done in this period.

\section{BRITISH RESIDENCY AND THE MEDICAL SERVICE}

At the end of the seventeenth century war broke with India and an agreement was signed between the Nepal and British India governments in $1801 \mathrm{AD}$. Subsequently British residency got established in Kathmandu in 1802 AD. Prior to this there was no diplomatic mission in Nepal. Captain Knox as the resident and Dr FB Hamilton as the resident surgeon appointed for residency office in Nepal. After arriving in Kathmandu Dr Hamilton was busy on collection of the herbs, plants and seeds. ${ }^{7}$

The agreement between the British India and the Nepal government cancelled in $1804 \mathrm{AD}$ and residency staffs returned to India and war broke again. Sugauli agreement signed between Nepal and India in 1815 AD and British residency was re-established in $1816 \mathrm{AD}$. There is no mention in the history about the appointment of doctor in the re-established residency. It can be guessed that the British residents appointed at that time had some experience in medicine. This is supported by the paper published by resident Brian Hodson (1829-31 and 1833-1843 AD) in cholera and malaria in Nepal. It is also possible that a medical assistant might have been posted at that time. Dr. H.A. Oldfield was appointed as the resident doctor in 1850 to $1863 \mathrm{AD}$ in residency. Dr Oldfield has mentioned about major health problems of the Nepal such as smallpox, malaria, cholera, tuberculosis and problems related to childbirth. As there were no modern medicine facilities at that time he treated the ruling class on the recommendation of the then Prime Minister Rana Jung Bahadur. Oldfield also introduced vaccination in $1850 \mathrm{AD}$ in Nepal for first time, with vaccination of the children of the family of the Prime Minister Jung Bahadur. ${ }^{8}$

Dr Wright replaced Dr Oldfield in the British residency. In 1883 AD there was mention of another medical doctor, Dr. Adar Nath who treated the then Commander-in-Chief
General Dhir Shamsher. Likewise, Adar Nath treated General Bhim Shamsher too for abdominal colic in 1884 AD. It is not clear whether Adar Nath was a residency doctor or government doctor., ${ }^{9} 10$

\section{RANA PERIOD: STATE INITIATIVE TO ESTABLISH MEDICAL SERVICES}

Rana period, which lasted for 104 years, is the important era of health and hospital development in Nepal. In this period several hospitals and dispensaries were established both in the modern medicine and traditional medicine as a state initiative. As there were no qualified health personnel in Nepal all doctors and nurses were brought from India.

Khokna Leprosy Asylum was the first health institution established by the state in 1857 AD to isolate the leprosy patients. ${ }^{11}$ As there was no treatment discovered for leprosy patients at that time, people with leprosy were just detained by the home department. At that time Surendra Bir Bikram Shah was the king and Jang Bahadur was the prime minister.

\section{PRIME MINISTER BIR SHAMSHER (1885-1901 AD): INTRODUCTION OF HOSPITAL SERVICES}

Tenure of the Prime Minister Bir Shamsher is remembered as the landmark for the health and hospital development in Nepal. During his premiership the first hospital of the country in modern medicine was established in Kathmandu in the year 1947 BS or 1889 AD. The hospital named collectively after the then King Prithvi Bir Bikram Shah (1880-1913 AD) and Prime Minister Rana Bir Shamsher as Prithvi- Bir Hospital. In the same year Cholera Hospital was established in Teku, Kathmandu near rope way station. Additional Prithvi-Bir group of hospitals were established in the same year in Birganj, Jaleshwar, Hanuman Nagar, Taulihawa and Nepalganj. Leprosy Hospital was also established in Tripureshwar. ${ }^{9}$

\section{PRIME MINISTER CHANDRA SHAMSHER (1902-1929 AD): NATIONAL NETWORK OF HOSPITALS AND DISPENSARIES}

After the death of the Prime Minister Bir Shamsher, Rana Chandra Shamsher became the Prime Minister of Nepal. He further established new hospitals and consolidated the previously established hospitals. Chandra Lok Hospital established in Bhaktapur in 1903 AD. The second-generation hospitals were established in the name of the then King Prithvi Bir Bikram and Prime Minister Chandra Shamsher as PrithviChandra group of hospitals. Prithvi-Chandra Hospitals were established in Palpa, Palhi, Doti, and Ilam. After the death of 
the King Prithvi Bir Bikram Shah, Crown Prince Tribhuvan Bir Bikram Shah (1913-1954 AD) became the King of the Nepal. New group of hospitals as Tribhuvan-Chandra Hospitals established in Dhankuta, Bhadrapur, Sarlahi, and Rangeli. In 1925 AD 64-bedded Tri-Chandra Military Hospital was established in Kathmandu in the commemoration of the war heroes of the First World War. Prithvi-Bir Hospital in Kathmandu was further strengthened with establishment of the separate Women's Hospital, radiology and laboratory units and Chandra Sales Dispensary. Nardevi Ayurvedic Hospital was established in 1918 and parallel Ayurvedic dispensaries were established in districts along with the modern medicine hospitals. He also established Lalitpur Hospital in Patan in 1924 AD. The expansion work of Khokna Leprosy Asylum to sanatorium and construction of Tokha Tuberculosis Sanatorium were also started during the premiership of the Rana Chandra Shamsher. Eighteen hospitals and 14 dispensaries got established during his premiership. ${ }^{12,13}$

Kharga Hospital was established in Bajhang by Jaya Prithvi Bahadur Singh from non-governmental sector during the tenure of the Chandra Shamsher.

\section{PRIME MINISTER BHIM SHAMSHER 1929-1932 AD}

After the death of the Rana Chandra Shamsher, Rana Bhim Shamsher became the Prime Minister. He established Tri-Bhim Hospitals in Bhairahawa, Butwal and Bahadurganj. Ramghat dispensary at Pashupati was inaugurated in 1929 AD and further dispensaries were established in Sindhulimadi, Ramechhap, Okhaldhunga, and Pashupatinagar. ${ }^{12,13}$

\section{PRIME MINISTER JUDDHA SHAMSHER 1932-1945 AD}

After the death of Bhim Shamsher, Rana Juddha Shamsher became the Prime Minister. He established Tri-Juddha group of hospitals in 1931 AD in Dharan and in 1940 in Bhimphedi, Bardiya, and Kailali. Tokha Tuberculosis Sanatorium (40 bed) came in operation in $1935 \mathrm{AD}^{14}$ and Leprosy Asylum in Khokana, Kathmandu was upgraded to sanatorium and new leprosy sanatorium constructed in Malunga, Syangja also came in operation in the same year. Leprosy department and treatment center was established at Pachali (shifted from Tripureshwar) in 1937 AD. ${ }^{11}$

\section{PRIME MINISTER - PADAM SHAMSHER (1945-1948 AD) AND MOHAN SHAMSHER (1948-1951 AD)}

Health services established by their predecessors were strengthened during their tenure. One health center was established in Sankhu in 1949. Homeopathic dispensary was opened and a chest clinic (1951) was started in Bir Hospital. School health program initiated during this period. ${ }^{12,13,14}$

\section{POST -DEMOCRACY PERIOD}

This period is also very important period in the history of Nepal. Several new health programs were declared and secondary and tertiary care health institutions were established in this period. This period also opened opportunity to nongovernmental organizations and private sector to provide health care. This period can also be divided into several phases.

\section{NEW HEALTH POLICIES AND PROGRAMS AND INVOLVEMENT OF NON GOVERNMENTAL ORGANIZATIONS HEALTH CARE (NGOS) - 1951-1963 AD}

In this period planned development process was started in Nepal and more health institutions established to increase the access of people to basic health care. Dispensaries established earlier were converted to heath centers or upgraded to hospitals. Health training institutions were established to train the health care technicians and nurses within the country.

Health centers were established in Banepa (1954), Dailekh (1955), Ramnagar Bhutaha (1956), and Chainpur, Sankhuwasabha (1957). Biratnagar Hospital, Dang Hospital and Baglung Hospital opened in 1956, 1957 and 1958 respectively. Kanti Hospital was established in 1962 in Kathmandu. Health programs for control of malaria (1958), smallpox (1962), leprosy (1963) and family planning and maternal and child health (1962) were started. In 1958 Health Ministry implemented new health policy-one health center in each 105 electoral constituency. With this policy one health center opened in 1958, two in 1959, 40 in 1960, 14 in 1961, 10 each in 1962 and 1963 respectively. In the year 1963 there were 32 hospitals and 104 health centers in the public sector. ${ }^{13}$

NGO hospitals funded by missions were established in Lalitpur (Shanta Bhawan Hospital - 1954), Bhaktapur (Suryabinayak Hospital -1954), Banepa (Scheer Memorial Hospital 1957), Kaski (Pokhra Shining Hospital - 1957), Gorkha (Amp Pipal Hospital -1957), Okhaldhunga (Okhaldhunga Hospital - 1963), Nawalparasi (Bulingtar Hospital - 1962) and Palpa (United Mission Hospital -1954). Leprosy Hospitals were established by the leprosy mission in Lalitpur (Anandban Leprosy Hospital -1963), Kaski (Green Pasteur Hospital -1957) and Dadeldhura (Dadeldhura Leprosy Hospital) in this period. Indra Rajya Laxmi Maternity Hospital (1958) was established by a national NGO in Thapathali, Kathmandu.

\section{REGIONALIZATION OF HEALTH SERVICES - 1964-1974 AD}

With the political and administrative division of the country into 75 districts and 14 zones, in 1964 regionalization of health 
services was started and new zonal hospitals providing comprehensive health care were established in Biratnagar, Rajbiraj, Janakpur, Birganj, Butwal, Pokhra and Nepalganj. Kanti Hospital was converted into children's hospital with the merger of the pediatric department of Bir Hospital. ICU/CCU services were opened for first time in the country in Bir Hospital. Nepal Tuberculosis Association opened Tuberculosis Hospital (1970) in Kalimati, Kathmandu. Some of the health centers were converted into health posts or upgraded to district hospitals during this period.

\section{EMERGENCE OF SINGLE SPECIALTY HOSPITALS AND IMPLEMENTATION OF PRIMARY HEALTH CARE SYSTEM (1975-1992) AD}

Single specialty hospitals were established during this period in psychiatry and eye. Long-term health plan was prepared and primary health care system was implemented. In public sector 775 Health posts at community level and district hospitals or bigger hospitals were established in all districts except Okhaldhunga, Kavre, Ramecchap, Rolpa, Dolpa, Humla, Syangja, Mugu and Kalikot. Bhadrapur hospital, Kailali hospital and Kanchanpur hospital upgraded to zonal hospitals. Gandaki Zonal Hospital was upgraded to Western Regional Hospital. National Tuberculosis Center was established in Sanothimi, Bhaktapur. Bir Hospital saw several changes - eye department merged with the eye hospital and gynaecology and obstetrics department merged with Maternity Hospital. Psychiatry department also merged with the new Mental Hospital in Lagankhel, Lalitpur. Teku Hospital was separated from Bir Hospital control and received independent infectious disease hospital status and upgraded to national hospital. Homeopathic Hospital was upgraded and shifted to a new building in Pulchok, Lalitpur. Traditional medicine dispensaries too were established at community level. High-level health manpower production was started and lower level health manpower production intensified. Smallpox eradication goal was achieved and new program on expanded immunization was started.

Tribhuvan University Teaching Hospital (1986) and Birendra Police Hospital (1984) were established in Kathmandu in public sector. Army Hospital was shifted to a new building in Tahachal. NGO sector also actively contributed in health by establishing Nepal Eye Hospital (1980) in Kathmandu and several eye hospitals were established (Biratnagar, Lahan, Janakpur, Birganj, Bharatpur, Bhairahawa, Pokhra, Dang, Nepalganj, and Dhangadhi) outside Kathmandu. Orthopedic hospital was also established in Jorpati, Kathmandu while Khunde and Phaplu hospitals were established in Khumbu region. Additional eye hospitals was opened in Kathmandu eg Tilganga Eye Hospital and Lion's Eye Care Center by NGO. Some small hospitals were established in private sector.

\section{EMERGENCE OF TERTIARY CARE CENTERS AND EXPANSION OF PRIMARY HEALTH CARE AND GROWTH OF PRIVATE HEALTH INSTITUTIONS 1993- 2002 AD}

Tertiary care services were started in neurosurgery, cardiac surgery and cancer from public sector. One hundred eighty health centers at electoral constituency level and 3107 sub health posts at village development committee level was established and many traditional medicine treatment centers were also established. Health program was started to eradicate polio and DOTS strategy was initiated to control tuberculosis. Leprosy elimination program was also started. District hospitals were established in Ramechhap, Humla and Syangja. BP Koirala Memorial Cancer Hospital (1995) in Chitwan and Shahid Gangalal National Heart Center (1997) in Kathmandu were established. One medical college hospital - BP Koirala Institute of Health Science Teaching Hospital (1993) from public sector and Manipal Medical College Teaching Hospital (1997), Bharatpur Medical College Teaching Hospital (1998), Bhairahawa Medical College Teaching Hospital (1999), Nepal Medical College Teaching Hospital (1997), Kathmandu Medical College Teaching Hospital (2000), and Nepalganj Medical College Teaching Hospital (2002), were established from private sector providing secondary and tertiary medical care services and education. The nursing and allied health worker training programs were also privatized. Private hospitals as big as 200 bedded were established (B \& B Hospital, Om Hospital and National Medicare Hospital) to provide secondary and tertiary medical care. First Dental Hospital (National Dental Hospital) and Dental College and Teaching Hospital (People's Dental College) of the country was established in the Kathmandu by private sector.

The non-governmental organization also contributed in health care by establishing hospitals in Damak, Chaurjahari, Doti and Dhulikhel. Maternal and Child Health Hospitals established in Butwal and Bhaktapur. Epilepsy Hospital was established in Dolakha. An orthopedic hospital for rehabilitation of children was opened in Banepa. Sushma Koirala Memorial Plastic and Reconstructive Surgery Hospital (1999) was started in Sankhu. Leprosy Hospital was opened in Lalgadh, Sarlahi. Cancer Hospital was established in Bhaktapur. Birthing centers were established in several parts of the country. Treatment centers with indoor facilities were opened for high altitude sickness, tuberculosis and snakebite in many parts of the country. Dadeldhura Leprosy Hospital was changed to General Hospital and Lamjung District Hospital was handed to NGO by government. New health care concept such as Hospice Nepal (2001) was started for patients terminally ill from incurable diseases in Kathmandu. 


\section{CLOSURE OF THE HOSPITALS}

Many health institutions were closed due to restructuring of health services and other administrative reasons. The Tokha Tuberculosis Sanatorium and Malunga Leprosy Sanatorium have been closed. Some private hospitals and nursing homes were also closed. Mission hospitals in Nawalparasi, Suryabinayak and Pokhra were closed permanently and Amp Pipal Mission Hospital, Gorkha is preparing to operate differently after the management of mission left. Dharan Hospital and the British-Gurkha Army Hospital in Dharan merged initially to form Eastern Regional Hospital and now were transferred to BP Koirala Institute of Health Sciences. Lalitpur Hospital and Shantabhawan Hospital merged as Patan Hospital as a model of government and non-government partnership in health care and is put under the unified governing board. Bir Hospital had the major changes in organization and service repeatedly.

\section{CONCLUSION}

History of modern health services is not long in Nepal though the Christian missionaries were introduced it in $16^{\text {th }}$ century. The traditional medicine could not develop as an effective health care system despite of the main health system of the country for more than one century. Effort of government, nongovernmental organizations and private sector is satisfactory to provide health care and education. There seems lack of policy on hospital establishment and management. The health facilities are concentrated in few cities and some districts do not have any district hospitals till date while other districts such as Morang, Rupendehi and Kapilvastu has more than two public sector hospitals. Capital city Kathmandu has large number of hospitals with tertiary treatment facilities. Outside Kathmandu, hospitals are concentrated in Biratnagar, Janakpur, Birganj, Bharatpur, Pokhra, Butwal, Bhairahawa and Nepalganj city areas. Establishing a single specialty hospital rather than a comprehensive health care hospital is found in increasing trend in last three decades, which is not preferred in many countries because of administrative cost, efficiency of the institution and convenience of the patients. The regionalization plan of health services in public sector initiated in 1960s seems weakened as no comprehensive care hospitals such as zonal and regional hospital have been established after 1985.

\section{REFERENCES}

1. Regmi Jagdish Chandra. Lichchhavi History. Tribhuvan University, Nepal Asian Study Center, 1996.

2. KC Surendra. Ancient and Medieval Nepal. Pairabi Publications, 1998.

3. Gautam Dinanath. Educational Directory of Nepal. Lumbini Book Store, 2001.

4. Sharma Gopinath. Development of Educational Administration of Nepal. Lumbini Book Store, 1999.

5. Paudel Loknath. Development of Education in Nepal. Bidyarthi Pustak Bhandar, 1994.

6. Landan Perceval. History of Nepal. Aadarsha Enterprises, 2001:2.

7. Yadav Pitamber Lal. Political History of Nepal, 1996.

8. Landan Perceval. History of Nepal. Aadarsha Enterprises, 2001:1.

9. Dixit Hemang. Health Care During the Rana Days. Journal of Kathmandu Medical College, 2002: 4:115-119.

10. Dixit Hemang. Medicine in Old Days. The Quest for Health, First Edition, 1995: 15-19.

11. Mali IB. Leprosy Services in Nepal. Journal of Nepal Medical Association, 1966:3:3: 225-229.

12. Sharma Debi Prasad. History of Medicine of Nepal (Nepali). Ratna Pustak Bhandar, Kathmandu, 1990.

13. Dixit Siddimani, Dixit Hemang. Allopathic Medicine in Nepal. Journal of Nepal Medical Association, 1966:4: 8-15.

14. Das GSL. Tuberculosis in Nepal. Past, Present and Future. Journal of Nepal Medical Association, 1966: 4:358-360.

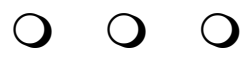

